\title{
Herpes zoster ophthalmicus with hemiplegia due to vasculopathy
}

\author{
Awad Magbri*, Eussera El-Magbri, and Mariam El-Magbri \\ Dialysis Access Center of Pittsburgh, PA \& Life-care Hospital, Pittsburgh, USA
}

\section{Case presentation}

The patient is 68 year old white female with a history of type 2 diabetes, hypertension, hyperlipidemia, and congestive heart failure. She is functionally independent. She had chicken- pox as a child but did not received varicella zoster vaccine. In 2014 she had sudden onset of right facial throbbing headache for 2 days. Subsequently, she developed a rash of varicella zoster viral (VZV) infection in the distribution of right ophthalmic branch of the trigeminal nerve. The rash involves the tip of the nose and the patient was complaining of dizziness and impaired vision. She was seen by the ophthalmologist who put her on antiviral medication because of the threat to her vision.

Two days after the appearance of the rash she complained of headache and weakness of the left side of the body. Neurological examination at that time revealed evidence of left sided stroke in the distribution of the anterior/middle cerebral arteries. A CT scan followed by MRI of the brain confirmed the presence of stroke in the distribution of the MCA at the grey-white matter junction.

A spinal tap along with broader set of diagnostic laboratory tests involving VZV- IgG antibodies, CSF mononuclear pleocytosis, and positive intra-thecal synthesis of VZV-IgG as shown by dissociation of serum to CSF ratio of anti-VZV IgG confirms the diagnosis. Even through, the VZV-DNA was negative. Eventually, a diagnosis of VZVinfection (herpes zoster ophthalmicus with vasculopathy and stroke) was made.

Treatment was started with prednisone $60 \mathrm{mg} /$ day and tapered over 2 weeks, gabapentin $200 \mathrm{mg}$ three times daily, and valacyclovir $500 \mathrm{mg}$ Q12 hrs. For 14 days. The patient made a remarkable recovery with resolution of her neurological deficit, and subsidence of and eventually disappearance of the rash of VZV. Luckily, her vision was not impaired. Three months later she was in a good health, very active in her daily livings, and denied post-herpetic neuralgia (PHN).

\section{Discussion}

The advent of polymerase chain reaction (PCR) and VZV DNA sequencing along with anti-VZV antibody detection have improved clinical diagnosis of VZV infection. These advances in diagnostic technologies have made identifications of various sequelae of VZV pathology easier. The VZV-vasculopathy including, myelitis, meningoencephalitis, cerebral ataxia, and cranial polyneuritis can be diagnosed with or without VZV-rash [1].

PCR diagnosis of VZV infection has high sensitivity (95\%), and specificity approaching (100\%), with no cross reactivity to other herpes viruses [2]. It is rapid, inexpensive, and the specimen can be obtained from CSF, broncho-alveolar lavage, saliva, serum, or whole blood [3]. VZV-specific antibodies associated with amplification by PCR for VZV-DNA are essential for VZV diagnosis [3]. Post-herpetic neuralgia $(\mathrm{PHN})$ is the most common and dreadful complication from reactivation of VZV. After vaccination the incidence of PHN dropped from $18.5 \%$ to $6.0 \%$ in patients older than 70 years [4]. When shingles occurs despite vaccination, the extent of the rash and severity of the complications of the virus, like neuropathic pain may be less obvious which confound the diagnosis [4-6]. VZV-DNA and specific antiVZV antibodies made possible the diagnosis of zoster complications especially in the absence of typical VZV-rash.

Historically, VZV vasculopathy are presented with acute hemiplegia after contralateral herpes zoster opthalmicus or as arteriopathy in children with varicella [7-10]. The clinical spectrum broadens in recent years after refinement of VZV diagnosis. These pathological phenomena include, vasculopathy (transient ischemic attacks or stroke), multifocal VZV-vasculopathy with temporal artery infection resembling giant cell arteritis (GCA), extra-cranial vasculopathy, aneurysms with and without subarachnoid hemorrhage, arterial dissection etc. as shown in Table 1.

The pathogenesis of VZV-vasculopathy results from reactivation and transmission of the virus through the axons of the nerves to arteritis where productive infection is established. This leads to pathological vascular remodeling with inclusion bodies, multinucleated giant cells, herpes virions and VZV- DNA and antigen deposition in the wall of the vessels, venous sinuses, and dural structure [10-13]. The antigen antibody reaction with recruitment of the CD4+ and CD8+ T- cells, macrophages, and rare CD20+ B-cells culminates in to inflammation of the vessel involved [14]. The culprit vessel infected by the virus would show disrupted internal elastic lamina, a thickened intima by cells expressing actin and myosin heavy chain [10]. All the three layers of the arteries infected by the virus would show inflammatory cell infiltrate. The thickened adventitia is associated with inflammation of the vasa vasorum in the early VZV-vasculopathy $[15,16]$. These altered pathology lead to arterial caliber irregularities, and contractility that produce aneurysmal dilation, thrombosis, and narrowing of the vessels with attended cut of the blood supply to the tissue in the territories of the artery involved.

Correspondence to: Awad Magbri, Dialysis Access Center of Pittsburgh, PA \& Life-care Hospital, Pittsburgh, USA, Tel: +1 4122715106; E-mail: elmagbri@ hotmail.com

Key words: VZV infection, vasculopathy, giant cell arteritis, PCR-amplification of DNA, intra-cranial and extra-cranial vasculitis

Received: October 17, 2017; Accepted: October 25, 2017; Published: October 27, 2017 
Table 1. VZV-vasculopathy.

\begin{tabular}{|l|l|}
\hline Ischemic and hemorrhagic stroke & $\begin{array}{l}\text { VZV-DNA, IgG (+), MRI-ischemic or } \\
\text { hemorrhagic lesions in grey-white matter } \\
\text { distribution }\end{array}$ \\
\hline $\begin{array}{l}\text { Multifocal VZV-vasculopathy with } \\
\text { temporal artery infection and GCA }\end{array}$ & $\begin{array}{l}\text { GCA-biopsy negative, CSF and TA biopsy } \\
\text { may be positive for VZV infection }\end{array}$ \\
\hline Extra-cranial vasculopathy & $\begin{array}{l}\text { Occlusion, vasospasm, or thrombosis of the } \\
\text { extra-cranial arteries. }\end{array}$ \\
\hline Aneurysm/hemorrhage & $\begin{array}{l}\text { Aneurysms and hemorrhage in the intra- } \\
\text { cranial arteries }\end{array}$ \\
\hline Arterial dissection and dolichoectasia & $\begin{array}{l}\text { Dissection of the carotid arteries associated } \\
\text { with VZV-infection and trauma }\end{array}$ \\
\hline Cranial neuropathies & $\begin{array}{l}\text { Cranial neuropathies after VZV-infection, } \\
\text { not uncommon. CNs III, IV, V2,3 and } \\
\text { VI (CST), IX, X, XI and XII (ascending } \\
\text { pharyngeal artery) }\end{array}$ \\
\hline Venous sinus thrombosis & $\begin{array}{l}\text { MRI may show filling defects in the } \\
\text { cerebral sinuses }\end{array}$ \\
\hline Spinal cord infarction/peripheral thrombotic \\
disease & $\begin{array}{l}\text { Acute onset myelopathy, diagnosed } \\
\text { by diffusion-weighted MRI and CSF } \\
\text { virological analysis. Arterial or venous } \\
\text { thrombosis of the lower libs due to VZV- } \\
\text { hypercoagulability. }\end{array}$ \\
\hline
\end{tabular}

Involvement of different vessels by the virus result in the protean manifestations:

1- Ischemic and hemorrhagic stroke.

2- Multifocal VZV- vasculopathy with temporal artery infection resembling GCA.

3- Inflammation and occlusions of the extra-cranial vessels like common carotid arteries, central retinal artery occlusion, internal carotid artery occlusion, thrombosis, and vasospasm $[17,18]$.

4- Arterial dissection and ectasia predisposed by minor trauma [19].

5- Cerebral venous sinus thrombosis has been reported as complication of VZV infection [20,21].

6- Spinal cord myelopathy and infarction have also been seen with VZV - infection as seen by diffusion-weighted MRI [22,23] and analysis of CSF for VZV infection [24].

\section{Conclusion}

VZV-vasculopathy is characterized by protean manifestations as a results of involvement of large and small vessel vasculitis of intra-cranial, extra-cranial vessels, venous sinuses, and cranial neuropathies. VZVvasculopathy can presented with or without rash and the diagnosis is clinched by CSF specific VZV-IgG, and VZV-DNA by PCR techniques along with imaging of the brain. Confirmation of intra-thecal synthesis of anti-VZV antibodies is the key to diagnosis. Treatment of VZVvasculopathy requires intra-venous acyclovir therapy, the course may be prolonged in immunosuppressed patients.

\section{Funding}

The authors have no financial disclosure.

\section{References}

1. Gnann JW jr (2002) Varicella-zoster virus: atypical presentations and unusual complications. J Infect Dis 186 (suppl 1): S91-S98

2. Cohen JI (2013) Clinical practice: Herpes zoster. N Engl J Med 369: 255-263. [Crossref]

3. Gershon AA, Gershon MD (2013) Pathogenesis and current approaches to control of varicella-zoster virus infection. Clin Microbiol rev 26: 728-743.
4. Oxman MN, Levin MJ, Johnson GR (2005) A vaccine to prevent herpes zoster and post-herpetic neuralgia in older adults. $N$ Engl J Med 352: 2271-2284

5. Schmader KE, Oxman MN, Levin MJ, Johnson G, Zhang JH, et al. (2012) Persistence of the efficacy of zoster vaccine in the shingles prevention study and the short-term persistence substudy. Clin Infect Dis 55: 1320-1328. [Crossref]

6. Chaves SS, Zhang J, Cliven R (2008) Varicella disease among vaccinated persons: clinical and epidemiological characteristics. 1997-2005. J Infect Dis 197 (suppl 2): S127-S131.

7. Kang JH, HO JD, Chen YH, Lin HC (2009) Increased risk of stroke after a herpes zoster attack: a population-based follow up study. Stoke 40: 3443-3448.

8. Lin HC, Chien CW, Ho JD (2010) Herpes zoster ophthalmicus and the risk of stroke: a population-based follow-up study. Neurology 74: 792-797. [Crossref]

9. Braun KP, Bulder MM, Chabrier S, Kirkham FJ, Uiterwaal CS, et al. (2009) The course and outcome of unilateral intracranial arteriopathy in 79 children with ischaemic stroke. Brain 132: 544-557. [Crossref]

10. Nagel MA, Traktinskiy I, Azarkh Y (2011) Varicella zoster virus vasculopathy: analysis of virus infected arteries. Neurology 77: 364-70

11. Gilden DH, Kleinschmidt-DeMasters, Wellish M (1996) Varicella zoster virus, a cause of waxing and waning vasculitis. Neurology 47: 1441-1446.

12. Mayberg M, Langer RS, Zervas NT, Moskowitz MA (1981) Perivascular meningeal projections from cat trigeminal ganglia: possible pathway for vascular headache in man. Science 213: 228-230.

13. Mayberg MR, Zervas NT, Moskowitz MA (1984) Trigeminal projections to supratentorial pial and dural blood vessels in cats demonstrated by horseradish peroxidase histochemistry. J Comp Neurol 223: 46-56.

14. Dal Canto AJ, Swanson PE, O'Guin AK (2001) INF-gamma action in the media of the great elastic arteries, a novel immunoprivileged site. J Clin Invest 107: 15-22.

15. Frid MG, Brunetti JA, Burke DL (2006) Hypoxia-induced pulmonary vascular remodeling requires recruitment of circulating mesenchymal precursors of a monocyte/ macrophage lineage. Am J pathol 168: 659-669.

16. Stenmark KR1, Yeager ME, El Kasmi KC, Nozik-Grayck E, Gerasimovskaya EV, et al. (2013) The adventitia: essential regulator of vascular wall structure and function. Annu Rev Physiol 75: 23-47. [Crossref]

17. Bhayani N, Ranade P, Clark NM, McGuinn M (2008) Varicella-zoster virus and cerebral aneurysm: case report and review of the literature. Clin Infect Dis 47: e1-3. [Crossref]

18. Liberman AL, Nagel MA, Hurley MC (2014) Rapid development of nine cerebral aneurysms in varicella zoster virus vasculopathy. Neurology (in press).

19. Dalton CM, Jager HR, Losseff NA, Greenwood RJ (2008) Neurological picture. Varicella zoster virus and intra-cranial dolichoectasia in a late adult cancer survivor. $J$ Neurol Neurosurg Psychiatry 79: 573.

20. Saito K, Moskowitz MA (1989) Contribution from the upper cervical dorsal roots and trigeminal ganglia to the feline circle of Willis. Stroke 20: 524-526.

21. Siddiqi SA, Nishat S, Kanwar D (2012) Cerebral venous sinus thrombosis: association with primary varicella zoster virus infection. J Stroke Cerebrovasc Dis 8: 917.

22. Devinsky O, Cho ES, Petito CK, Price RW (1991) Herpes zoster myelitis. Brain 114 1181-1196. [Crossref]

23. Kenyon LC, Dulaney E, Montone KT, Goldberg HI, Liu GT, et al. (1996) Varicellazoster ventriculo-encephalitis and spinal cord infarction in a patient with AIDS. Acta Neuropathol 92: 202-205. [Crossref]

24. Orme HT, Smith AG, Nagel MA, Bert RJ, Mickelson TS, et al. (2007) VZV spinal cord infarction identified by diffusion-weighted MRI (DWI). Neurology 69: 398-400. [Crossref]

Copyright: (C2017 Magbri A. This is an open-access article distributed under the terms of the Creative Commons Attribution License, which permits unrestricted use, distribution, and reproduction in any medium, provided the original author and source are credited. 